\title{
When nuclear medicine radiological protection meets biological COVID-19 protection
}

\author{
Jonathan Vigne ${ }^{1,2,3} \cdot$ Nicolas Aide $^{1,4} \cdot$ Damien Peyronnet $^{1,2} \cdot$ Catherine Nganoa $^{1} \cdot$ Denis Agostini $^{1} \cdot$ Pierre Barbey $^{5}$
}

Received: 26 March 2020 / Accepted: 1 April 2020 / Published online: 9 May 2020

(C) Springer-Verlag GmbH Germany, part of Springer Nature 2020

Dear Sir,

Since the first cases reported in China in December 2019 [1], coronavirus disease 2019 (COVID-19) caused by a novel coronavirus, now referred to as severe acute respiratory syndrome coronavirus 2 (SARS-CoV-2), became a pandemic raising a lot of concern to control $[2,3]$. At the time of preparing this manuscript (24th of March 2020), the World Health Organization reported globally that the number of confirmed cases has reached more than 300,000 cases in almost all countries with an increasing majority of these reported from EU/EEA countries and the UK. Currently, Europe is facing the rapid and relentless increase of the outbreak which already caused a major burden especially in Italy, Spain, and France [4]. To date, it is admitted that about $80 \%$ of individuals with COVID-19 have a mild disease (i.e., a respiratory tract infection with or without pneumonia) and most of them recover [5]. Inversely, in more than 10\% of cases, COVID-19 develops into a more severe disease requiring hospitalization while the remaining cases experience critical presentation requiring intensive care. Therefore, European and worldwide nuclear medicine will be more and more confronted to

This article is part of the Topical Collection on Letter to the Editor.

Jonathan Vigne

vigne-jo@chu-caen.fr

1 Department of Nuclear Medicine, CHU de Caen Normandie, Normandie University, UNICAEN, F-14000 Caen, France

2 Department of Pharmacy, CHU de Caen Normandie, Normandie University, UNICAEN, F-14000 Caen, France

3 Normandie Univ, UNICAEN, Institut National de la Santé et de la Recherche Médicale, PhIND, Institut Blood and Brain @ Caen-Normandie, Centre Cyceron, F-14000, Caen, France

4 Normandie University, UNICAEN, INSERM ANTICIPE, F-14000 Caen, France

5 IMOGERE Laboratory, Normandie University, UNICAEN, F-14000 Caen, France manage COVID-19-positive patients. In this context, the nuclear medicine community that is fully aware and trained regarding the radiological risk has now to deal with the biological COVID-19 risk. Despite some specificities, these two imperceptible risks display common features that may contribute to facilitate the understanding and the preparation of nuclear medicine staff regarding this urgent situation.

\section{Patient management}

A first screening should be advised on the patient's arrival in the department by asking simple questions about eventual experienced symptoms and background including fever, dry cough, dyspnea, and contact with a confirmed case. Practically, a highly visible note at the reception desk inviting patients to self-declare these symptoms may be helpful. Also, knowing that the median duration of viral shedding is estimated at 20 days in patients that recovered from COVID-19 [6], it is important to be cautious with these patients because data are lacking regarding their contagiousness. A specific notice indicated the good hygiene practice especially informing about the localization of handwashing facilities or at least access to hand sanitizer. An illustrated protocol for an effective hand wash may be pertinent to prevent surface contamination and the waiting area.

Nuclear medicine staff is already used to work in a dichotomized "cold" and "hot" area because of radiological protection. By analogy, COVID-19-suspected patients should be placed in a separate waiting area with security distance to respect (e.g., materialized by duct tape on the floor) and most importantly a medical mask (also known as a surgical mask) must be given to them with recommendations to adjust it well. If necessary, physicians may refer some patients to the appropriate infectious disease consultations. In the case of COVID19-confirmed patients, they must wear a medical mask and the nuclear medicine department should optimize their management. If possible, COVID-19-positive patients may be 
scheduled at the end of the day to limit their contact with the other patients and an appropriate biodecontamination protocol should be performed following their scans. As nuclear medicine departments are built based on radiological protection directives, they are designed with easy decontaminable surfaces which should facilitate the biological decontamination in the context of COVID-19. Recent data suggest that not only aerosols but also fomite transmission of SARS-CoV-2 are plausible since the virus can remain viable and infectious in aerosols for hours and on surfaces up to days [7]; these findings call for rigorous monitoring of hygiene in the department.

The fast-spreading of the outbreak led multiple governments to establish a lockdown. Therefore, lots of nuclear medicine departments are advised to delay non-urgent examinations while urgent scans such as myocardial perfusion scintigraphy for symptomatic patients or ${ }^{18} \mathrm{~F}$-fluoro-2-deoxyglucose $\left({ }^{18} \mathrm{~F}-\mathrm{FDG}\right)$ positron emission tomography/computed tomography (PET/CT) in oncological patients should be preserved. As nuclear medicine is mostly taking care of outpatients, the rescheduling of exams should most of the time be feasible. Importantly, prominent changes in blood coagulation of patients with SARS-CoV-2 infection have been reported with Ddimer, fibrin/fibrinogen degradation products, and fibrinogen substantially higher in infected patients [8]. Such parameters are associated with poor prognosis in patients with novel coronavirus pneumonia [9], so it is expected that COVID-19positive patients will be referred for lung scintigraphy. Because many ventilation systems are difficult to completely disinfect and because there are still unknown about the transmissibility of COVID-19, some institutions have decided to eliminate the ventilation part of the examination and only maintained the perfusion part for all patients [10]. Therefore, a combination of chest $\mathrm{CT}$ and lung perfusion scintigraphy seems safer.

\section{Protection of nuclear medicine staff}

Although biological COVID-19 protection is currently evaluated and bears specificities, it shares a common approach with radiological protection that is well mastered by nuclear medicine teams. The joint Table 1 gathers the different items to consider regarding these two potential risks. First, it is interesting to underline that the three principles that apply for external radiation safety (time, distance, and shielding) are also pertinent in the context of COVID-19 protection. Also, nuclear medicine facilities and especially the "hot" lab present some common features regarding collective protection with virology labs such as specific room ventilation, control of airborne particles, and confinement of the source (e.g., gloves box). Individual protective equipment will play a critical role to limit the virus nosocomial spreading and protect healthcare professionals. Nuclear medicine staffs are occasionally using
FFP 2 respirators (or N95 respirators) when taking care of patients with bacterial, fungal, or viral (e.g., influenza) respiratory infections. In the context of the COVID-19 pandemic, FFP 2 respirators are lacking and their use may then be reserved to medical staff that practices invasive respiratory procedures in intensive care and reanimation units, which are the most exposed. Already published data comparing the incidence of laboratory-confirmed influenza in healthcare personnel taking care of outpatients wearing either medical masks or N95 respirators resulted in no significant difference between the two groups [11]. Therefore, the wearing of medical masks should be considered for all nuclear medicine staff including cleaning staff for different reasons such as (1) the median incubation period was estimated to be around 5 days, and more than $97 \%$ of those who develop symptoms will do so within 11.5 days [12]; (2) asymptomatic presentations of the COVID-19 are presumably possible [13, 14], so it remains elusive to perfectly screen the whole staff; (3) medical masks prevent hand to face contact enabling to limit fomite transmission; and (4) the nuclear medicine teams that are on duties have to inevitably be in contact with vulnerable patients (e.g., patients with cardiovascular or oncological background). Also, working clothes, protective coveralls, gloves, hoods, face shields, and other protective equipment may be used to optimize protection. However, these materials will have to be cleaned or changed regularly. For materials suspected to be contaminated that cannot be thrown up or decontaminated, they may be hermetically packed, identified, and stored in a safe place for several days as radiocontaminated materials stored for decay before being re-used or evacuated.

Another key point is about the management of human resources in the nuclear medicine departments. It seems reasonable to reduce the number of people working at the same time to enable backup to assure an efficient turnover in case of infection in the team. Importantly, COVID-19-positive workers must stay quarantined at home. Close management of the team is critical to allow continuity of healthcare.

\section{Conclusion}

Radiology departments are preparing themselves to optimize the management of the outbreak [15]. Nuclear medicine departments equipped with $\mathrm{CT}$ hybrid cameras should check lung findings from SPECT/CT and PET/CT examinations. Indeed chest $\mathrm{CT}$ plays a critical role in the identification of COVID-19-positive patients [16]. Implementation of a robust plan in the nuclear medicine departments is required to prevent further nosocomial spread of the virus. Through this exceptional situation, radiological and biological risk prevention workers have much to learn from each other but also much to share. Starting from the well-mastered radiological protection 
Table 1 Comparison between the nuclear medicine radiological risk and the biological COVID-19 risk

\begin{tabular}{|c|c|c|}
\hline & $\begin{array}{l}\text { Nuclear medicine } \\
\text { radiological risk }\end{array}$ & Biological COVID 19 risk \\
\hline Risk physical nature & Aerosols, gaseous, liquid droplets & Aerosols \\
\hline \multicolumn{3}{|l|}{ Protection of workers } \\
\hline \multirow{2}{*}{ EU regulation } & Directive 2013/53/EURATOM & $\begin{array}{l}\text { Directive } 2000 / 54 / \mathrm{CE} \\
\text { Directive UE/2019/1833 }\end{array}$ \\
\hline & \multicolumn{2}{|c|}{$\begin{array}{l}\text { Directive } 89 / 656 / \mathrm{EEC} \text { and its last adaptation : Directive (EU) } \\
2019 / 1832 \text { (personal protective equipment at the workplace) }\end{array}$} \\
\hline Workplace aeraulic conditions & $\begin{array}{l}\text { Permanent mechanical } \\
\text { ventilation }\end{array}$ & $\begin{array}{l}\text { Permanent mechanical } \\
\text { ventilation }\end{array}$ \\
\hline Facilities surfaces & Easily decontaminable & Easily decontaminable \\
\hline Controlled areas & Yes with restricted access & Yes with restricted access \\
\hline Hazard signage (entrance) & $\begin{array}{c}\text { Different signages according to } \\
\text { the country }\end{array}$ & $\underbrace{\text { cte }}_{\substack{\text { Biohazard symbol used for all } \\
\text { countries }}}$ \\
\hline $\begin{array}{l}\text { Controlling the danger at the } \\
\text { source }\end{array}$ & Sorbonne, shielded gloves-box & Microbiological safety hood \\
\hline \multirow[t]{2}{*}{$\begin{array}{l}\text { Individual protective } \\
\text { equipment }\end{array}$} & $\begin{array}{l}\text { Working clothes, protective } \\
\text { coverall, gloves, hoods, face } \\
\text { shield, masks (full face masks } \\
\text { with different cartridges, FPP } \\
\text { filtering half-masks...) }\end{array}$ & $\begin{array}{l}\text { Working clothes, protective } \\
\text { coverall, gloves, hoods, face } \\
\text { shield, masks (FFP filtering } \\
\text { half-masks...) }\end{array}$ \\
\hline & \multicolumn{2}{|c|}{$\begin{array}{l}\text { Note: FFP masks filter at least } 80 \% \text { of aerosols (FFP1), } 94 \% \text { of } \\
\text { aerosols (FPP2) and } 99 \% \text { of aerosols (FPP3) respectively }\end{array}$} \\
\hline Ambient controls & $\begin{array}{l}\text { Routinely radiodetection } \\
\text { devices adapted to radiation } \\
\text { type } \\
\text { Immediate or rapid information }\end{array}$ & $\begin{array}{l}\text { Complex methodology } \\
\text { atmospheric checks and filter } \\
\text { analysis } \\
\text { late information }\end{array}$ \\
\hline Health monitoring & $\begin{array}{l}\text { External dosimetry } \\
\text { Anthropogammametry } \\
\text { Radiotoxicological analysis }\end{array}$ & $\begin{array}{l}\text { Routinely devices } \\
\text { (temperature) } \\
\text { Radiology imaging } \\
\text { Nasal swab sample and } \\
\text { molecular biology analysis }\end{array}$ \\
\hline \multicolumn{3}{|c|}{ Formation of workers and good practices } \\
\hline Rule 1: Time of exposure & $\begin{array}{l}\text { Exponential decay (physical } \\
\text { and biological half-live) }\end{array}$ & $\begin{array}{l}\text { Increased when close to } \\
\text { contagious subjects }\end{array}$ \\
\hline Rule 2 : Distance & $\begin{array}{l}\text { Inversely proportional to the } \\
\text { square of the distance }\end{array}$ & $\begin{array}{l}\text { Inversely linked to the distance } \\
\text { (at least } 1 \mathrm{~m} \text { recommended) }\end{array}$ \\
\hline Rule 3 : Shielding & $\begin{array}{l}\text { High density material to } \\
\text { attenuate radiation exposure } \\
\text { Screens in plastic material } \\
\text { (vinyl, Plexiglas...) }\end{array}$ & $\begin{array}{l}\text { Screens made of transparent, } \\
\text { flexible or rigid plastic } \\
\text { materials }\end{array}$ \\
\hline Gestural behaviours & $\begin{array}{l}\text { Avoid uncontrolled or } \\
\text { inadvertent gestures such as } \\
\text { hands to face contact }\end{array}$ & $\begin{array}{l}\text { Avoid uncontrolled or } \\
\text { inadvertent gestures such as } \\
\text { hands to face contact }\end{array}$ \\
\hline & & $\begin{array}{l}\text { Do not sneeze or cough in front } \\
\text { of a person }(*)\end{array}$ \\
\hline Surface decontamination & $\begin{array}{l}\text { Ensure the radiological } \\
\text { cleanliness of workplaces and } \\
\text { surfaces with decontaminant } \\
\text { cleaner }\end{array}$ & $\begin{array}{l}\text { Ensure the biological } \\
\text { cleanliness of workplaces and } \\
\text { surfaces with appropriate } \\
\text { chemical disinfectants and } \\
\text { antiseptics }\end{array}$ \\
\hline \multicolumn{3}{|l|}{ Harmfullness } \\
\hline External contamination & $\begin{array}{l}\text { Damage to the cutaneous basal } \\
\text { layer by radiations } \\
\text { Risk of transcutaneous transfer } \\
\text { of radioactive substances } \\
\text { (through skin lesions) }\end{array}$ & $\begin{array}{l}\text { Risk of transcutaneous transfer } \\
\text { of biological pathogens through } \\
\text { skin lesions }\end{array}$ \\
\hline Internal contamination & $\begin{array}{l}\text { Increased risk to be ill (mainly } \\
\text { radiocarcinogenesis) }\end{array}$ & $\begin{array}{l}\text { Increased risk to be ill and } \\
\text { contagious }\end{array}$ \\
\hline Delay to first symptoms & Up to years & Up to days \\
\hline \multicolumn{3}{|l|}{ Specific populations } \\
\hline Children & High sensitivity to radiations & $\begin{array}{l}\text { Low risk to COVID-19 but } \\
\text { contagious }\end{array}$ \\
\hline Elderly & Low sensitivity to radiations & $\begin{array}{l}\text { High risk to COVID-19 and } \\
\text { contagious }\end{array}$ \\
\hline Pregnancy & $\begin{array}{l}\text { Highest foetotoxic risk during } \\
\text { the first trimester }\end{array}$ & Low risk for the foetus \\
\hline Strategy to reduce spreading & Lockdown of the source & Lockdown of the population \\
\hline
\end{tabular}


would help nuclear medicine staff to integrate more rapidly the less-known biological COVID-19 protection.

\section{Compliance with ethical standards}

Conflict of interest The authors declare that they have no conflict of interest.

Ethical approval This article does not contain any studies with human participants or animals performed by any of the authors.

\section{References}

1. Du Toit A. Outbreak of a novel coronavirus. Nat Rev Microbiol. 2020;18:123

2. WHO Director-General's opening remarks at the media briefing on COVID-19 - 23 March 2020 [Internet]. [cited 2020 Mar 24]. Available from: https://www.who.int/dg/speeches/detail/whodirector-general-s-opening-remarks-at-the-media-briefing-oncovid-19\%2D\%2D-23-march-2020

3. Bedford J, Enria D, Giesecke J, Heymann DL, Ihekweazu C, Kobinger G, et al. COVID-19: towards controlling of a pandemic. The Lancet. 2020;395:1015-8.

4. Kinross P, Suetens C, Dias JG, Alexakis L, Wijermans A, Colzani $\mathrm{E}$, et al. Rapidly increasing cumulative incidence of coronavirus disease (COVID-19) in the European Union/European Economic Area and the United Kingdom, 1 January to 15 March 2020. Eurosurveillance. European Centre for Disease Prevention and Control. 2020;25:2000285.

5. Rapid risk assessment: Novel coronavirus disease 2019 (COVID19) pandemic: increased transmission in the EU/EEA and the UK sixth update [Internet]. [cited 2020 Mar 24]. Available from: https:// www.ecdc.europa.eu/en/publications-data/rapid-risk-assessmentnovel-coronavirus-disease-2019-covid-19-pandemic-increased

6. Zhou F, Yu T, Du R, Fan G, Liu Y, Liu Z, et al. Clinical course and risk factors for mortality of adult inpatients with COVID-19 in Wuhan, China: a retrospective cohort study. The Lancet. 2020;395:1054-62.
7. van Doremalen N, Bushmaker T, Morris DH, Holbrook MG, Gamble A, Williamson BN, et al. Aerosol and Surface Stability of SARS-CoV-2 as Compared with SARS-CoV-1. N Engl J Med. 2020;382:1564-7.

8. Han H, Yang L, Liu R, Liu F, Wu K-L, Li J, et al. Prominent changes in blood coagulation of patients with SARS-CoV-2 infection. Clinical Chemistry and Laboratory Medicine. 2020. https:// doi.org/10.1515/cclm-2020-0188.

9. Tang N, Li D, Wang X, Sun Z. Abnormal coagulation parameters are associated with poor prognosis in patients with novel coronavirus pneumonia. J Thrombosis Haemostasis [Internet]. [cited 2020 Mar 25];n/a. Available from: http:/onlinelibrary.wiley.com/doi/abs/ 10.1111/jth.14768.

10. COVID-19 and ventilation/perfusion (V/Q) lung studies - SNMMI [Internet]. [cited 2020 Mar 25]. Available from: https://www. snmmi.org/NewsPublications/NewsDetail.aspx?ItemNumber= 33543

11. Radonovich LJ, Simberkoff MS, Bessesen MT, Brown AC, Cummings DAT, Gaydos CA, et al. N95 respirators vs medical masks for preventing influenza among health care personnel: a randomized clinical trial. JAMA. 2019;322:824-33.

12. Lauer SA, Grantz KH, Bi Q, Jones FK, Zheng Q, Meredith HR, et al. The incubation period of Coronavirus Disease 2019 (COVID19) from publicly reported confirmed cases: estimation and application. Ann Intern Med. 2020. https://doi.org/10.7326/M20-0504.

13. Bai Y, Yao L, Wei T, Tian F, Jin D-Y, Chen L, et al. Presumed asymptomatic carrier transmission of COVID-19. 2020;323: 1406-1407.

14. Rothe C, Schunk M, Sothmann P, Bretzel G, Froeschl G, Wallrauch C, et al. Transmission of 2019-nCoV infection from an asymptomatic contact in Germany. N Engl J Med. 2020;382:970-1.

15. Kooraki S, Hosseiny M, Myers L, Gholamrezanezhad A. Coronavirus (COVID-19) outbreak: what the Department of Radiology should know. J Am Coll Radiol. 2020;17:447-51.

16. Ai T, Yang Z, Hou H, Zhan C, Chen C, Lv W, et al. Correlation of chest CT and RT-PCR testing in coronavirus disease 2019 (COVID19) in China: a report of 1014 cases. Radiology. 2020;200642. https://doi.org/10.1148/radiol.2020200642.

Publisher's note Springer Nature remains neutral with regard to jurisdictional claims in published maps and institutional affiliations. 